\title{
HUBUNGAN PROGRAM GERMAS TERHADAP KEBIASAAN HIDUP MASYARAKAT YANG TELAH DAN BELUM MENDAPATKAN SOSIALISASI DI WILAYAHKERJA PUSKESMAS KECAMATAN SUKARAME PALEMBANG
}

\author{
Tedi $^{2}$, Fadly $^{2)}$, Ridho $\mathbf{R}^{2)}$ \\ ${ }^{1,2)}$ Jurusan Farmasi Poltekkes Kemenkes Palembang
}

Diterima: 01 November $2018 \quad$ Direvisi : 10 November 2018 Disetujui: 17 November 2018

\begin{abstract}
ABSTRAK
Perubahan pola penyakit yang disebut dengan transisi epidemiologi menggeser perhatian kesehatan Indonesia kepada penyakit tidak menular. Pemerintah menyusun Gerakan Masyarakat Hidup Sehat (GERMAS) sebagai wujud dari nawa cita Presiden RI. Program Germas mengedepankan upaya preventif tanpa mengesampingkan upaya kuratif dan rehabilitatif dengan tiga indikator fokus Germas. Aktivitas fisik setiap hari, mengkonsumsi sayur dan buah setiap hari dan memeriksa kesehatan secara berkala. Tujuan dari penelitian ini untuk melihat hubungan program germas terhadap kebiasaan hidup masyarakat yang telah/belum mengetahui atau mendapatkan sosialisasi program germas. Penelitian ini adalah survey analitik dengan pendekatan cross sectional, penelitian ini dilakukan di Puskesmas yang terdapat di Kecamatan Sukarame Palembang yang dilakukan pada bulan Maret sampai Juni 2018. Data diuji dengan chi square dengan analisis cross tab menggunakan aplikasi analisa statistik. Hasil uji menunjukan bahwa nilai Assymp sig pearson's chi square sebesar 0.034 yang artinya bahwa Ho ditolak sehingga dapat diartikan ada hubungan antara program germas terhadap kebiasaan hidup masyarakat yang telah dan belum mendapatkan sosialisasi di wilayah kerja puskesmas Kecamatan Sukarame Palembang secara signifikan. Program Germas berhubungan secara signifikan terhadap kebiasaan hidup masyarakat yang telah/belum mengetahui atau mendapatkan sosialisasi program germas.
\end{abstract}

Kata kunci, trnssisi epidemilogi,penyakit tidak menular,germas

\begin{abstract}
Changes in the pattern of diseases called epidemiological transitions shift the attention of Indonesian health to non-communicable diseases. The government established the Healthy Living Society Movement (GERMAS) as a manifestation of the Nawacita of the Indonesian President. GERMAS puts forward preventive efforts without putting aside curative and rehabilitative efforts with three indicators of the GERMAS focus. Doing daily physical activity, eating vegetables and fruit every day and checking health are periodically. The purpose of this study is to see the correllation between the program of GERMAS on habits of the people who have not and have received socialization of GERMAS programs. This study was an analytical survey with a cross sectional approach, the study was conducted at Puskesmas located in Kecamatan Sukarame Palembang which was held from March to June 2018. The Data was tested by chi-square with cross-tab analysis using statistical analysis application. The test results showed that the Assymp sig Pearson's chi square value was 0.034, which means that Ho was
\end{abstract}


rejected so that it could be interpreted that there was a correllation between the GERMAS programs and the life habits of the people who had and had not been socialized in PUSKESMAS work area of Kecamatan Sukarame are significantly. The Germas program is significantly related to the life habits of people who had and had not got the GERMAS program socialization.

Keywords: epidemiological transmission, non-communicable diseases, GERMAS.

\section{PENDAHULUAN}

Kondisi kesehatan masyarakat di Indonesia kini semakin kompleks, hal ini disebabkan karena saat ini Indonesia mengalami perubahan pola penyakit yang biasa disebut dengan transisi epidemiologi (Irianto, 2014). Transisi epidemiologi timbul karena terjadinya perubahan pola perilaku dan pola penyakit pada masyarakat Indonesia yang disebabkan karena pola gaya hidup modern (Heryana, 2016).

Hal ini dapat di lihat dari meningkatnya prevalensi penyakit tidak menular (PTM) seperti diabetes mellitus (DM), pada hasil Riskesdas 2007 memiliki prevalensi $(1,1 \%)$ dan meningkat menjadi $(2,1 \%)$ pada Riskesdas 2013, hipertensi juga turut mengalami peningkatan dari $(7,6 \%)$ pada tahun 2007 menjadi $(9,5 \%)$ pada tahun 2013, stroke, jantung koroner, kanker dan lain sebagainya juga mengalami peningkatan angka prevalensi penyakit

Pada dasarnya penyakit tidak menular dapat dicegah dan disembuhkan dari pola hidup yang sehat dan prilaku yang sehat (Kemenkes RI, 2017). Pemerintah telah melakukan berbagai upaya pencegahan untuk meningkatkan derajat kesehatan masyarakat Indonesia. Namun, upaya tersebut masih belum menunjukan hasil yang signifikan. Melihat hal tersebut diperlukan upaya bersama untuk merubah perilaku hidup sehat yang melibatkan seluruh masyarakat Indonesia, tanpa membedakan usia, jenis kelamin, jenis pekerjaan, status sosial, status ekonomi dan lokasi tinggal (Kemenkes RI, 2017). Berdasarkan visi pembangunan nasional
"Terwujudnya Indonesia yang berdaulat, mandiri, dan berkepribadian berlandaskan gotong royong" maka di bentuklah sembilan agenda prioritas (Nawa Cita) Presiden Republik Indonesia. Salah satu nawa cita yang berperan dalam peningkatan kesehatan adalah nawa cita nomor lima yang menyatakan bahwa "Meningkatkan kualitas hidup manusia Indonesia". Kemudian hal tersebut selanjutnya disusun dalam Gerakan Masyarakat Hidup Sehat (Germas), hal ini juga diperkuat dengan Instruksi Presiden Republik Indonesia Nomor 1 tahun 2017 tentang Gerakan Masyarakat Hidup Sehat yang mengedepankan upaya promotif dan preventif tanpa mengesampingkan upaya kuratif dan rehabilitatif.

Menurut buku panduan Germas 2017, Germas adalah suatu tindakan yang sistematis dan terencana yang dilakukan secara bersama-sama oleh seluruh komponen bangsa dengan kesadaran, kemauan dan kemampuan berperilaku sehat untuk meningkatkan kualitas hidup. Fokus program germas tahun 2016-2017 adalah melakukan aktivitas fisik setiap hari, mengkonsumsi sayur dan buah setiap hari dan memeriksa kesehatan secara berkala. Program Germas telah dilaksanakan hampir satu tahun dengan anggaran dana yang terbilang luar biasa telah menjadi panduan aktif masyarakat untuk menerapkan hidup sehat. Puskesmas sebagai salah satu fasilitas kesehatan turut memberikan sosialisasi ke masyarakat di wilayah kerja masing-masing puskesmas. Menteri Kesehatan mengakui bahwa kesadaran dan pola pikir masyarakat masih menjadi kendala utama dalam penerapan pola hidup germas. Mengingat 
belum adanya laporan ataupun penelitian mengenai program Germas, maka peneliti melakukan penelitian untuk mengkaji kebiasaan hidup masyarakat setelah adanya sosialisasi program Germas dengan judul penelitian "Hubungan Program Germas Terhadap Kebiasaan Hidup Masyarakat yang Telah dan Belum Mendapatkan Sosialisasi di Wilayah Kerja Puskesmas Kecamatan Sukarame Palembang”.

\section{METODE PENELITIAN}

\section{Jenis Penelitian}

Penelitian ini merupakan penelitian observasi dengan pendekatan analitik cross sectional, yaitu penelitian yang dilakukan pada satu waktu dan satu kali untuk melihat pengaruh program germas terhadap kebiasaan hidup masyarakat di wilayah kerja puskesmas Kecamatan Sukarame Palembang.

\section{Waktu dan Tempat Penelitian}

Objek penelitian yang akan digunakan adalah Penelitian ini dilakukan pada bulan Maret-Juni 2018 di Puskesmas yang terletak di Kecamatan Sukarame Palembang.

\section{Populasi dan Sampel}

\section{Populasi}

Populasi pada penelitian ini adalah masyarakat yang terdaftar di wilayah kerja puskesmas di Kecamatan Sukarame Palembang dalam waktu kunjungan satu minggu sebanyak 2.640 orang

\section{Sampel}

Teknik pengambilan sampel yang akan digunakan adalah teknik purposive sampling yaitu teknik penentuan sampel berdasarkan kriteria yang ditentukan peneliti untuk dapat di anggap mewakili karakteristik populasinya (Supardi dan Surahman, 2014). Apabila sampel penelitian lebih dari 100 maka sampel dapat di ambil antara $10-15 \%$ atau 20-25\% atau lebih (Arikunto, 2013). Sampel pada penelitian ini diambil $10 \%$ dari rata-rata jumlah masyarakat yang datang dalam waktu satu minggu ke wilayah kerja puskesmas di Kecamatan Sukarame Palembang

\section{Cara Pengumpulan Data}

1. Penulis mendata masyarakat yang akan dijadikan sampel kemudian mendatangi masyarakat yang terdata sesuai kriteria.

2. Penulis meminta kesediaan masyarakat untuk menjadi responden penelitian dengan memberikan penjelasan mengenai tujuan penelitian.

3. Penulis memberikan penjelasan mengenai cara pengisian kuesioner.

4. Penulis akan menunggu responden selesai mengisi lembar kuesioner dan apabila responden mengalami kesulitan dalam memahami pertanyaan maka akan dijelaskan kembali oleh penulis.

5. Setelah selesai maka kuesioner dikumpulkan kembali kepada peneliti dan diperiksa keengkapannya.

\section{Alat Pengumpulan Data}

Alat yang digunakan untuk memgumpulkan data dalam penelitian ini adalah kuesioner, alat tulis, alat perekam.

\section{Variabel Penelitian}

Variabel Independent : Sosialisasi Program Germas

Variabel Dependent : Kebiasaan Hidup

\section{Cara Pengolahan dan Analisis Data}

Data yang diperoleh disajikan dalam bentuk tabel kemudian di analisis dengan menggunakan cross tab yang berfungsi untuk mengetahui ada tidaknya pengaruh antara kedua variabel. Analisa data menggunakan program SPSS versi 24 for windows. Pengambilan keputusan Jika nilai sig $>0,05$, Ho diterima Jika nilai sig $<0,05$, Ho ditolak 


\section{HASIL PENELITIAN}

\section{Hasil}

Hasil didapat bahwa responden yang telah mengetahui/mendapatkan sosialisasi program germas dan memiliki kebiasaan baik sebanyak 93 orang, sedangkan responden yang telah mengetahui/ mendapatkan sosialisasi program germas dan memiliki kebiasaan kurang baik sebanyak 61 orang. Untuk responden yang belum mengetahui/mendapatkan sosialisasi program germas dan memiliki kebiasaan hidup baik sebanyak 54 orang, sedangkan responden yang belum mengetahui/ mendapatkan sosialisasi program germas dan memiliki kebiasaan kurang baik sebanyak 60 orang.

Tabel 1. Distribusi responden yang telah/belum mengetahui/mendapatkan sosialisasi program germas di wilayah kerja Puskesmas Kecamatan Sukarame Palembang.

\begin{tabular}{lccc}
\hline \multicolumn{1}{c}{ Puskesmas } & $\begin{array}{c}\text { Program Telah } \\
\text { Mengetahui }\end{array}$ & $\begin{array}{c}\text { Germa Belum } \\
\text { Mengetahui }\end{array}$ & Jumlah \\
\hline Pukesmas Sosial & 60 & 40 & 100 \\
Puskesmas Sukarame & 55 & 45 & 100 \\
Puskesmas Tl.Betutu & 39 & 29 & 68 \\
\hline \multicolumn{1}{c}{ Total } & 154 & 114 & 268
\end{tabular}

Tabel 2. Distribusi responden yang memiliki kebiasaan hidup baik dan kurang baik di wilayah kerja puskesmas kecamatan sukarame palembang.

\begin{tabular}{|c|c|c|c|c|c|}
\hline \multirow{2}{*}{ Puskesmas } & \multicolumn{2}{|c|}{ Keiasaaan Hidup } & \multirow[b]{2}{*}{ Kur Baik } & & \multirow{2}{*}{ Jumlah } \\
\hline & Baik & $\%$ & & $\%$ & \\
\hline Pukesmas Sosial & 52 & $52 \%$ & 40 & $48 \%$ & 100 \\
\hline Puskesmas Sukarame & 59 & $59 \%$ & 45 & $41 \%$ & 100 \\
\hline Puskesmas Tl.Betutu & 36 & $53 \%$ & 29 & $47 \%$ & 68 \\
\hline
\end{tabular}

Tabel 9. Hubungan Program Germas terhadap kebiasaan hidup masyarakat yang telah dan belum mendapatkan sosialisasi di wilayah kerja puskesmas kecamatan sukarame palembang.

\begin{tabular}{ccccccc}
\hline \multirow{2}{*}{$\begin{array}{c}\text { Program } \\
\text { Germas }\end{array}$} & \multicolumn{2}{c}{ Kebiasaan Hidup } & & \multirow{2}{*}{ Assymp } & Odd & CI \\
& Baik & Kurang & Total & Sig & Ratio & $95 \%$ \\
\hline Ya & 93 & 61 & 154 & & & 1,038 \\
Tidak & 54 & 60 & 114 & 0,034 & 1,694 & - \\
\hline Total & 147 & 121 & 268 & & & 2,763
\end{tabular}




\section{PEMBAHASAN}

\section{Karakteristik Responden}

Jumlah total responden sebanyak 268 responden yang terdiri dari 100 responden Puskesmas Sosial, 100 responden Puskesmas Sukarame dan 68 responden Puskesmas Talang Betutu. Usia responden yang paling mendominasi adalah berusia $>40$ sebanyak $208 \quad(77,61 \%)$ responden. Kelompok pendidikan terakhir yang paling banyak adalah SMA sebanyak $150(55,97 \%)$ responden. Dari 268 responden terdapat 121 orang memiliki riwayat penyakit tidak menular (PTM), diantaranya adalah Batu Ginjal (1,65\%), Kolesterol (15,70\%), Asam Urat $(21,48 \%)$, Stroke $(0,82 \%)$, Diabetes Mellitus $(14,87 \%)$, Hipertensi $(36,36 \%)$ dan Asma (9,10\%).

\section{Program Germas}

Program germas menjadi salah satu tugas fasilitas kesehatan seperti Puskesmas untuk memberikan sosialisasi ataupun memberikan penjelasan baik secara lisan, tulisan ataupun tindakan kepada masyarakat untuk meningkatkan derajat kesehatan. Dari 268 responden terdapat $154(57,46 \%)$ responden yang telah mengetahui/mendapatkan sosialisasi tentang program germas dan sebanyak $114(42,54 \%)$ responden yang belum mengetahui/mendapatkan sosialisasi tentang program germas.

\section{Kebiasaan Hidup}

Hasilnya menunjukan bahwa terdapat $147(54,85 \%)$ responden di wilayah kerja Puskesmas Kecamatan Sukarame Palembang yang memiliki kebiasaan hidup dengan kategori baik sebanyak 121 $(45,15 \%)$ responden di wilayah kerja Puskesmas Kecamatan Sukarame Palembang memiliki kebiasaan hidup dengan kategori kurang baik. Hal ini menunjukan bahwa masyarakat di wilayah kerja Puskesmas Kecamatan Sukarame Palembang dapat dikategorikan baik. Hasil ini juga tidak terlalu jauh dari data program percepatan pembangunan dan sanitasi keluarga di Kecamatan Sukarame yang ber perilaku hidup bersih dan sehat pada tahun 2010 sebanyak 57,3\%.

\section{Hubungan Program Germas terhadap kebiasaan hidup masyarakat yang telah dan belum mendapatkan sosialisasi}

Berdasarkan hasil penelitian dengan uji chi square dengan menggunakan analisis crosstab dengan kepercayaan 95\% didapatkan nilai Assymp sig pearson's chi square sebesar 0.034. Dari hasil tersebut dapat disimpulkan bahwa Ho ditolak sehingga dapat ditarik kesimpulan ada hubungan antara program germas terhadap kebiasaan hidup masyarakat yang telah dan belum mendapatkan sosialisasi di wilayah kerja puskesmas Kecamatan Sukarame Palembang secara signifikan. Nilai Odd Ratio $(\mathrm{OR})=1,694$ menunjukan bahwa program germas memiliki pengaruh 1,694 kali terhadap kebiasaan hidup masyarakat di wilayah kerja Puskesmas Kecamatan Sukarame Palembang. Dalam hal ini semakin banyak masyarakat yang mengetahui / mendapatkan sosialisasi tentang program germas maka semakin banyak masyarakat yang memiliki kebiasaan baik dan sebaliknya, semakin banyak masyarakat yang tidak mengetahui / mendapatkan sosialisasi tentang program germas maka semakin banyak pula masyarakat yang memiliki kebiasaan kurang baik. Penelitian ini juga tidak jauh berbeda dengan hasil penelitian yang dilakukan oleh Pinasih (2018) menyatakan bahwa bahwa lansia yang tidak mengetahui program germas atau dengan tingkat pengetahuan rendah tidak melakukan praktik germas.

\section{KESIMPULAN}

Ada hubungan antara
germas terhadap kebiasaan
masyarakat yang telah dan belum


mendapatkan sosialisasi di wilayah kerja puskesmas Kecamatan Sukarame Palembang secara signifikan. Masyarakat di wilayah kerja Puskesmas Kecamatan Sukarame Palembang memiliki kebiasaan baik dalam melakukan aktivitas fisik setiap hari dan Puskesmas Talang Betutu memiliki persentase tertinggi dalam pelaksanaan indikator ini. Namun, aktivitas senam sehat bugar belum dilakukan secara rutin oleh masing-masing puskesmas dan kurangnya kesadaran dari masyarakat.

Kebiasaan baik dalam Indikator penyediaan pangan sehat dan percepatan perbaikan gizi sudah dilakukan dengan baik dan Puskesmas Sosial memiliki persentase tertinggi dalam pelaksanaan indikator kedua ini. Namun, komponen mengkonsumsi buah 2-3 kali dalam sehari masih sangat jarang dilakukan oleh masyarakat.

Masyarakat di wilayah kerja Puskesmas Kecamatan Sukarame Palembang memiliki kebiasaan baik dalam melakukan pemeriksaan kesehatan secara rutin setiap enam bulan sekali, walaupun persentase yang dimiliki dari masing-masing puskesmas tidak lebih dari setengah. Komponen pemeriksaan belum seluruhnya di lakukan oleh masyarakat karena puskesmas seringkali kehabisan stok alat untuk pemeriksaan kesehatan khususnya pemeriksaan kadar gula darah dan kadar kolesterol dan hal ini juga menjadi kelemahan kuesioner peneliti.

\section{SARAN}

Bagi peneliti selanjutnya yang ingin melakukan penelitian yang berkaitan dengan program germas diharapkan dapat mengamati ketersediaan alat kesehatan/alat pemeriksaan dalam indikator pemeriksaan kesehatan secara rutin setiap enam bulan sekali khususnya pemeriksaan tekanan darah bagi penderita hipertensi, pemeriksaan kadar gula darah dan kadar kolesterol bagi penderita diabetes mellitus dan kolesterol dengan berbagai variabel.

\section{DAFTAR PUSTAKA}

Budiman, Riyanto, A. 2013. Kapita Selekta Kuesioner Pengetahuan dan Sikap Dalam Penelitian Kesehatan. Salemba Medika, Jakarta, hal 1

Heryana, Ade, 2016. Transisi Epidemiologi. Universitas Esa Unggul. Jakarta.

Irianto, Koes, 2014. Epidemiologi Penyakit Menular dan Tidak Menular Panduan Klinis. AlfabetaCv. Bandung. Hal 198

Kemenkes RI, 2007. Riset Kesehatan Dasar 2007. Kementerian Kesehatan Republik Indonesia. Jakarta.

Kemenkes RI, 2011. Buku Panduan Promosi Kesehatan di Puskesmas. Kementerian Kesehatan Republik Indonesia. Jakarta.

Kemenkes RI, 2013. Riset Kesehatan Dasar 2013. Kementerian Kesehatan Republik Indonesia. Jakarta.

Kemenkes RI, 2016. Buku Panduan Germas. Gerakan Masyarakat Hidup Sehat. Kementerian Kesehatan Republik Indonesia. Jakarta.

Kemenkes RI, 2017. Warta Kesmas Edisi 01. Kementerian Kesehatan Republik Indonesia. Jakarta.

Menteri Kesehatan RI, 2007. Keputusan Menteri Kesehatan Nomor 58 Tahun 2007 Tentang Pedoman Pelaksanaan Promosi Kesehatan di Puskesmas. Menteri Kesehatan Republik Indonesia. Jakarta. 
Menteri Kesehatan RI, 2014. Peraturan Menteri Kesehatan Nomor 75 Tahun 2014 Tentang Pusat Kesehatan Masyarakat. Menteri Kesehatan Republik Indonesia. Jakarta.

Notoatmodjo, Soekidjo, 2003. Pendidikan Dan Perilaku Kesehatan. Rineka Cipta. Jakarta.

Pinasih, Amalia. 2018. Praktik GERMAS (Gerakan Masyarakat Hidup Sehat) 2017 Pada Lansia di Puskesmas Jenggawah Kabupaten Jember. Universitas Jember. Jawa Timur.

Pokja Sanitasi Kota Palembang, 2010. Program Percepatan Pembangunan Sanitasi Permukiman (PPSP). Palembang.

Presiden RI, 2009. Undang-Undang No.36 Tahun 2009 Tentang Kesehatan. Presiden Republik Indonesia. Jakarta.

Presiden RI, 2017. Instruksi Presiden Republik Indonesia Nomor 1 Tahun 2017 Tentang Gerakan Masyarakat Hidup Sehat. Presiden Republik Indonesia. Jakarta.

Prihatini \& Hermina, 2016. Gambaran Konsumsi Sayur dan Buah Penduduk Indonesia dalam Konteks Gizi Seimbang: Analisis Lanjut Survei Konsumsi Makanan Individu (SKMI) 2014. Pusat Penelitian dan Pengembangan Upaya Kesehatan Masyarakat. Jakarta.

Suleman, Kasman, 2012. Studi Tentang Penerapan Perilaku Hidup Bersih dan Sehat Masyarakat di Desa Bilungala Kecamatan Bonepantai Kabupaten Bone Bolango Tahun 2012. Universitas Negeri Gorontolo. Gorontolo. 